\title{
Alexander Yao Cobbinah* Suffixed plurals in Baïnonk languages: Agreement patterns and diachronic development
}

\author{
https://doi.org/10.1515/jall-2017-0007
}

\begin{abstract}
This paper re-evaluates hypotheses about the agreement behaviour of nouns using plural suffixes in the Baïnounk languages (Niger Congo/ Atlantic/ North Atlantic). Although these languages dispose of a large and complex prefixing noun class systems which are involved in expressing number distinctions, a subgroup of nouns uses a suffix for pluralisation. It is shown here that plural-suffixing nouns do not engage in the typologically rare process of phonological agreement copying as has been claimed previously. Instead, they are prefixed nouns, triggering alliterative agreement. Several scenarios about the origin and further development of the plural suffixes are presented. Synchronic data suggest that plural suffixes are older than the split of Nyun-Buy languages from a common ancestor. It is highly unlikely that it is borrowed from Mandinka, a regionally influential lingua franca which does not have noun classes. Instead, it seems plausible that plural suffixes have arisen through internal processes in which animacy and collective semantics have played a role. Potential candidates for a source morpheme for the plural suffix include a plural morpheme from the verbal domain or alternatively an associative plural. The role and impact of language contact and large scale borrowing on the extent of plural suffixation in the various Baïnounk languages is discussed.
\end{abstract}

Keywords: Atlantic languages, noun class, agreement, historical linguistics, language contact

\section{Introduction}

The Baïnounk languages are a cluster of about seven related but not mutually intelligible languages spoken between southern Senegal and northern Guinea

Bissau. Baïnounk Guñaamolo is the largest Baïnounk language, spoken in the north-west of Ziguinchor around the village of Niamone, Baïnounk Gubëeher is mainly spoken to the south-west of Ziguinchor in the village of Djibonker,

*Corresponding author: Alexander Yao Cobbinah, Department of Linguistics, SOAS, University of London, London, UK, E-mail: a.cobbinah@hotmail.com 
speakers of Baïnounk Guñun concentrate in Djifanghor east of Ziguinchor and Gujaher in the area east of Ziguinchor and in northern Guinea-Bissau. Other varieties of which no data is available include the variety of Tobor, north of Ziguinchor, and the north-eastern varieties that are possibly close to extinction, spoken towards the Gambian border and around Sedhiou (Denis Creissels, p.c.). The ensemble of the Baïnounk languages and their closest relatives, the languages Kobiana (also called Buy) and Kasanga (also called Gugëca), spoken in northern Guinea Bissau have in my terminology been referred to as the Nyun group (see Cobbinah 2013), although other linguists working on these languages refer to the group as Nyun-Buy, a term I will also adopt in this publication. The Nyun-Buy group has traditionally been classified (Sapir 1971; Greenberg 1963) as being a subgroup within the East-Senegal Guinea branch of the Atlantic family of the Niger-Congo phylum, though the validity as well as the internal structure of Atlantic is currently under review. Newer attempts at the genetic classification of the Greenbergian Atlantic family by Segerer and Pozdniakov (to appear) group the Nyun-Buy languages as an independent branch of North Atlantic. All known Nyun-Buy languages have very complex noun class systems comprising up to 30 noun class prefixes. These prefixes encode singular, plural and collective plural. Noun classes trigger agreement on modifiers such as adjectives, numerals and pronouns (see example 1). Alongside the more canonical plural marking via noun class prefixes, suffixed plural morphemes are attested in all languages of the Nyun-Buy group, see (2) for an example from Baïnounk Gubëeher representative of Baïnounk languages, for data from Kobiana see Voisin (2015a, 2015b), for data from Kasanga see Wilson (2007).
a. bu-rul
bu-way
CL.bu-mouth AGR.bu-wide
'wide mouth'
(Gubëeher, field notes)
b. i-rul i-way
CL.i-mouth AGR.i-wide
'wide mouths'

(2) a. bë-jid bë-ruk

CL.ba-girl AGR.ba-other

'another girl'

(Gubëeher, field notes)

b. bë-jid-én ba-naak- an

Cl.ba-girl-PL AGR.ba-two-PL

'two girls' 
The agreement patterns of these suffixed plurals in Baïnounk languages are the topic of this paper. Although the phenomenon of plural suffixes is attested in all Nyun-Buy languages, the data available and presented here is exclusively from Baïnounk languages, mainly due to the scarcity of data available for Kasanga and to a lesser extent for Kobiana. Due to the genetic relation between the Baïnounk languages and Kobiana/Kasanga as well as the structural similarities of the noun class systems of the two subgroups it is implied that the evolution of plural suffixes predates the split between these languages. An account valid for Baïnounk should therefore be applicable to Kobiana and Kasanga, although this is not explicitly attempted in this paper. Nouns with suffixed plurals have been the subject of theoretical interest and debate. It has been argued by Sauvageot (1967: 232, 1987: 19) for the Baïnounk language Guñaamolo that nouns compatible with plural suffixes are prefixless, and that the agreement patterns of some of these nouns involve copying of the CV onset from the noun onto the agreeing target. In essence, by assuming that a subgroup of plural-suffixed nouns copy their agreement prefix directly from the onset of the noun root, he suggests that agreement prefixes in Baïnounk Guñaamolo constitute an open class with a potentially unlimited number of morphemes. In major publications on noun classification (Dixon 1982; Aikhenvald 2003), Baïnounk Guñaamolo has henceforth been presented as a language with phonological agreement-copying.

On the basis of Sauvageot's $(1967,1987)$ description of noun class and agreement in Baïnounk Guñaamolo, Dobrin (1995) labels the phonological copying agreement supposedly evidenced in Guñaamolo "literal alliterative concord (LAC)". In 1995: 137) definition of LAC “agreement in this case is not with a noun prefix, because the noun of course has none. Instead, agreement is with the initial CV sequence of the noun stem [italics in original]". Dobrin's analysis is based on the assumptions that the nouns in question are indeed prefixless and that LAC is a synchronically productive process in Baïnounk languages. The expectation is that Baïnounk agreement markers potentially include all attested CV combinations found in noun onsets, making agreement prefixes an open class. Such a system would be typologically extremely rare among the languages of the world. Another language that might be a candidate for LAC is, according to Dobrin, the Papuan language Arapesh. According to recently conducted research, two Atlantic languages might turn out to be candidates for LAC, Landuma (Sumbatova, p.c.) and Baga Mandori (Seidel to appear a). Dobrin (1995, 1998) claims that LAC is in violation of the Principle of Phonology-Free Syntax (PPFS). PPFS had been claimed by Zwicky and Pullum (1986); (see also Miller et al. 1997) to be a universal principle of grammar, stating that "In the grammar of a natural language, rules of syntax make no reference to phonology (Miller et al. 1997)." This implies that syntax can only access morphological 
categories of a noun, like noun class, in order to determine agreement, but cannot directly access the phonological form of the noun. On the other hand, phonology can determine noun class membership, but not a syntactic process like agreement. PPFS has engendered academic debates on the status of various phenomena as to whether or not they violate this stipulated universal (e.g. Hetzron 1972; Zwicky and Pullum 1986). Dobrin (1995, 1998, 2012) inserts the Baïnounk Guñaamolo material into this debate, arguing for Baïnounk languages to be considered a case disproving PPFS as a universal principle. In reply to Dobrin, Dimitriadis (1997) and Aronoff (1997) have argued against this claim.

In this paper, I present evidence that speaks against the agreement-copying hypothesis, on the grounds that newly available data on various Baïnounk languages, mainly Gubëeher and Guñaamolo, shows that the nouns in question are prefixed and that their agreement is a case of regular prefixed alliteral agreement. Neither the nouns with this type of agreement nor the agreement prefixes constitute an open class. In both languages, the number of nouns engaging in plural marking via suffixes and alliteral agreement is limited. Indeed, most loans are assigned to a default agreement type with non-alliterative agreement. Refuting the validity of phonological copying in the first place, disqualifies the data on noun class agreement from Baïnounk Guñaamolo and other Baïnounk languages from being included in a debate on the consequences for the validity of PPFS as a universal principle.

The bulk of the data presented here is from Baïnounk Gubëeher, gathered during various fieldtrips between 2009 and 2016. Utterances that are part of the published DoBeS corpus 'Bainounk' are identified by the file name of the recording they occur in. The corpus is hosted at 'The Language Archive' of the Max Planck Institute for Psycholinguistics, Nijmegen, and can be accessed under https://hdl.handle.net/1839/00-0000-0000-0016-3656-0@view. Data from Gubëeher without a specified source are from my unpublished field notes or from my lexical database, which is also unpublished. For the data from Baïnounk Gubëeher the codified orthography, a version of which has been adopted for most Senegalese languages, is used. Vowel length is indicated by writing the vowel twice: /aa/ = [a:] etc. The letters 'c', ' $x$ ' and ' $n$ ' correspond to their IPA value; graphemes differing from IPA are:

\begin{tabular}{|l|l|l|l|l|l|}
\hline Orthography & IPA & Orthography & IPA & Orthography & IPA \\
\hline ë & {$[ə]$} & o & {$[?]$} & $\tilde{n}$ & {$[\mathrm{n}]$} \\
\hline $\mathrm{e}$ & {$[\varepsilon]$} & ó & {$[\mathrm{o}]$} & $\mathrm{y}$ & {$[\mathrm{j}]$} \\
\hline é & {$[\mathrm{e}]$} & $\mathrm{j}$ & {$[\mathrm{\jmath}]$} & & \\
\hline
\end{tabular}


Newly available data from Baïnounk Guñaamolo and other Nyun-Buy languages will be considered as well (Lüpke to appear; Quint 2015; Voisin 2015a; Voisin 2015b; Bao-Diop 2013; Bao-Diop 2015). ${ }^{1}$

The first part of this paper is a discussion of plural-suffixed nouns, their agreement patterns and an assessment of the claim that these nouns engage in agreement-copying. This includes a basic description of the noun class system of Baïnounk Gubëeher, as representative of a typical noun class system of a Baïnounk language. It is followed by a discussion of Serge Sauvageot's account of Baïnounk Guñaamolo and a critical review of this data. In the second part of this paper, I propose a data-driven hypothesis on the origin and historical development of suffixed plural marking within the Baïnounk languages based on the notion of animacy, integrating both internal (grammaticalisation) as well as external (language contact) factors.

\section{Noun class and agreement in Baïnounk Gubëeher}

Nouns in Baïnounk Gubëeher can be either prefixed or prefixless. Number distinctions, for those nouns which do so, can be expressed through prefixes as well as through suffixes (see Cobbinah and Lüpke 2014). For purely prefixed nouns, plurality is expressed by a change of prefix. A large subset of nouns, about one fourth of all nouns that express a singular/plural distinction, form plurals by suffixing the nasal suffix $-\mathbf{V n}$, the vowel of the suffix being determined by rules of vowel harmony. These nouns can be either prefixed or prefixless. The only indication of plurality is the plural suffix; the prefix is either the same or equally absent for singular and plural. On the basis of these criteria three major agreement types can be established for Baïnounk Gubëeher nouns. Table 1 gives an overview of the types of nouns relevant in this context. For a full account of the entire noun class system the reader is referred to Cobbinah (2013), for specifications on the expression of number see Cobbinah and Lüpke (2014).

The majority of count nouns in Baïnounk Gubëeher, here labelled "Type 1", distinguish singular and plural by choice of noun class prefix. These nouns

1 I thank Friederike Lüpke, Sylvie Voisin and Sokhna Bao-Diop for sharing their field notes, observations and unpublished data relevant in the context of the phenomena discussed here. 
Table 1: Types of nouns in Baïnounk Gubëeher depending on the expressions of plural number.

\begin{tabular}{llll}
\hline & Prefix mutation & Plural suffix & Agreement \\
\hline Type 1 & different prefix in singular and plural & none & (mostly) alliterative ${ }^{2}$ \\
Type 2a & same prefix in singular and plural & Yes & alliterative or non-alliterative \\
Type 2b & no prefix & Yes & alliterative or non-alliterative \\
\hline
\end{tabular}

occur in pairs (singular/plural paradigms) or triads (singular/count plural/ plural), cf. in example (3)-(5). ${ }^{3}$

(3) bu-tuk bu-dé

CL.bu-pumpkin AGR.bu-big

'big pumpkin'

(4) i-tuk i-dé i-naak

CL.i-pumpkin AGR.i-big AGR. i-big

'two big pumpkins'

(5) ba-tuk bë-dé

CL.ba-pumpkin AGR.ba-big

'big pumpkins'

Agreement for these nouns is prefixed and mostly alliterative, i.e. the prefix on the agreeing target has an identical or at least similar form of the prefix on the noun with some variation between agreement targets and phonological processes like vowel harmony operating between the root and the prefix. Due to this vowel harmony, the vowel /a/ can in some cases occur as /ë/; the prefix bë-, is thus an allomorph of the prefix ba- (cf. example (5).

The plural-suffixing nouns that do have prefixes are here referred to as type 2a. Example (6) shows a noun exhibiting this type of noun class agreement. Like for the majority of 2a nouns agreement is alliterative, i.e. the form of the noun class prefix and of the agreement prefix is the same or similar. Their prefix status

2 It should be noted that for some agreement classes agreement is not fully alliterative for all types of agreement targets. For a detailed list of agreement morphology see Cobbinah (2013). 3 Almost all of the noun class markers which occur in these number marking paradigms can also occur on nouns which are lacking a number distinction such as mass nouns, substances, abstract nouns etc. 
can be shown by substitution tests, e.g. by forming diminutives, whose prefixes replace the noun class prefix (see example 7).

(6)
a. bë-kér
bë-dé
CL.ba-chicken AGR.ba-big
'big chicken'

b. bë-kér-én

bë-dé-én

CL.ba-chicken-PL AGR.ba-big-PL

'big chickens'

(7) ko-kér

CL.ko-chicken

'small chicken'

A small number of nouns in this category, most of which are prefixed with ji-, have prefixes and plural suffixes but no alliterative agreement, like the example in (8). Agreement targets of nouns like jifek 'pig' in ( 8) are prefixed with a- in their singular and plural forms, and plurality is marked with the suffix -Vn. This type of agreement is referred to as default agreement and is also used for prefixless nouns. Again, prefix status can be shown by substitution with the diminutive prefix ko-, as shown in example (9).

a. ji-fek ë-dé

CL.ji-pig AGR.a-big

'big pig'

b. ji-fek-en ë-dé-en

CL.ji-pig-PL AGR.a-big-PL

'big pigs'

(9) ko-fek

CL.ko-pig

'little pig'

The nouns referred to as type $2 \mathrm{~b}$ are prefixless. The proportion of loanwords among the nouns of this agreement type is very high, since the majority of lexical items from languages without noun class markers (French, Kriolu ${ }^{4}$, Mandinka) or without noun class prefixes (Wolof) are assigned to this type.

4 Kriolu is here used to refer to the Portuguese-based Creole spoken in Guinea Bissau and Casamance. 
The majority of type $2 \mathrm{~b}$ nouns trigger default agreement prefixed with a- on their targets, irrespective of the phonological form of the noun, like shown in example (10). The substitution test (11) shows that these nouns are truly prefixless.

(10) a. koona ë-dé

house AGR.a-big

'big house'

b. koona-n ë-dé-en

house-PL AGR.a-big-PL

'big houses'

(11) ko-xoona

CL.ko-house

'small house'

Very few nouns which according to the substitution test applied above have to be regarded as prefixless exhibit alliterative agreement. Only two nouns, féébi 'goat' and fëcir 'monkey', both with fa- agreement, are known to belong to this subtype of $2 \mathrm{~b}$ agreement (see example 12). Historically, they most probably are cases of fusion between stem and a possibly formerly independent noun class prefix. Here again, the substitution test (13) shows that these nouns are prefixless.
a. féébi fë-dé goat(Cl.fa) AGR.fa-big 'big goat'
b. féébi-en fë-dé-én
goat(CL.fa)-PL AGR.fa-big-PL
'big goats'

\section{(13) ko-féébi \\ CL.ko-goat \\ 'little goat'}

In my analysis of the noun class system of Baïnounk Gubëeher, the majority of nouns are either prefixed with alliterative agreement or non-alliterative agreement, or they are prefixless and have non-alliterative agreement. For the small set of nouns that have prefixes, pluralise using a suffix and engage in alliterative agreement, prefix status for these onsets of these nouns can be shown by applying substitution tests using diminutive or augmentative prefixes. This view is 
incompatible with the initial analysis put forth by Sauvageot and the theoretical consequences of this analysis elaborated by Dobrin, claiming that Baïnounk languages engage in productive phonological agreement-copying whereby prefixless nouns use the onset of their stems as agreement prefixes, thus creating an open class of agreement morphology.

\section{Previous analyses of plural suffixes in Baïnounk languages}

In his brief description of the Baïnounk Guñaamolo noun class system, 1967, 1987) differentiates two large agreement types, prefixed nouns and prefixless nouns. The "prefixed nouns" both singular and plural, triggering alliterative, prefixed agreement on determiners, numerals, adjectives and interrogatives (Sauvageot [1967: 231] and Sauvageot [1987: 18]). The inventory of noun class prefixes established by Sauvageot for Baïnounk Guñaamolo is presented in Table 2.

Table 2: Noun class markers of Baïnounk Guñaamolo according to Sauvageot (1967: 227).

\begin{tabular}{|c|c|c|c|c|}
\hline \multicolumn{3}{|c|}{ Singular } & \multicolumn{2}{|l|}{ Plural } \\
\hline Class & Prefix & & Class & Prefix \\
\hline 1 & u- & & & \\
\hline 2 & i- & & 5 & ñaN- \\
\hline 3 & ra- & & & \\
\hline 4 & si- & & 6 & muN- \\
\hline 7 & gu- & & 8 & ha- \\
\hline 9 & bu- & & 10 & iN- \\
\hline 11 & kò-/ko- (d & ve) & 12 & kò-/ko- (diminutive) ${ }^{6}$ \\
\hline 13 & da- (augm & & 14 & di- $(\text { augmentative) })^{7}$ \\
\hline 15 & ba- & mass plural & & \\
\hline 16 & di- & mass plural for fruits & & \\
\hline 17 & ti-/bi-/pi- & mass plural "quantité illimité" & & \\
\hline 18 & ja- & mass plural diminutive & & \\
\hline
\end{tabular}

5 Figuring as "Type I" or "syntagme composé de deux monèmes" in 1987: 18).

6 According to Bao-Diop (2013) more detailed account and my own field notes the plural of the diminutive ko- is ño- in Baïnounk Guñaamolo, as it is in Baïnounk Gubëeher. It is ñi- in Baïnounk Gubelor and ja- or ñi- in Baïnounk Guñun (Quint 2015).

7 According to Bao-Diop (2013) more detailed account and my own field notes the plural noun class and agreement prefix of the. augmentative is din-. 
Interestingly a- is not accepted as a noun class prefix, although Sauvageot (1987) implicitly recognises its prefix status by noting that it can be substituted by other prefixes, such as diminutives and augmentatives. A reason for that might be that $\mathbf{a}$ - is also the default agreement of the majority of prefixless nouns, so that nouns prefixed with a- are counted as prefixless based on the shared agreement.

The second class of nouns are described by Sauvageot as "prefixless nouns". 8 These prefixless nouns constitute about one third of the lexicon, amounting to 200 out of 800 nouns (Sauvageot 1967: 229) or 400 out of 1200 nouns (Sauvageot 1987: 20). These are characterised by forming their plural with the suffix $-\mathbf{\nabla}$, a nasalised vowel whose quality is determined through vowel harmony with the vowel of the noun stem. In subsequent publications on Baïnounk Guñaamolo (Bao-Diop 2013; Bao Diop 2015) and other Baïnounk varieties the plural suffix is represented by a vowel followed by a velar nasal: -Vn. 1987: 20) suggests that the suffixed plural marking is a result of prolonged contact with classless languages, most notably Mandinka. The Baïnounk Guñaamolo suffix $-\tilde{\mathbf{V}} / \mathbf{- V \eta}$ is thus interpreted as a calque, or even a direct borrowing, of the Mandinka plural suffix -lu (with an allophone -nu in a nasal context). This claim is critically assessed in Section 4.3 of this paper.

In terms of agreement, these supposedly prefixless nouns are further divided into two types of agreement behaviour by Sauvageot:

1. Agreement type I nouns. Henceforth referred to as "type I nouns" or "agreement copying nouns" whose "initial CV sequence of the noun plays the role of the noun class prefix for agreement in singular as well as plural, being thus invariable" (Sauvageot 1967: 232, translation mine).

2. Agreement type II nouns. with non-alliteral default agreement in a- (before adjectives and numerals) or -no (on any other targets), irrespective of the phonological shape of the noun (Sauvageot 1967: 232 translation mine).

The following examples are provided by Sauvageot for a prefixed noun (14), for “agreement-copying” type I nouns (15), and prefixless nouns with default agreement (16).

\section{a. gu-sol gu-fer}

CL.gu-shirt AGR.gu-white

'white shirt'

Guñaamolo, Sauvageot 1987: 18

8 They figure as sans préfixe de classe 'without noun class prefixes' in 1967: 229), and as substantif[s] de type II 'type II nouns' or as [composé] d'un monème unique 'consisting of a single entity' in Sauvageot (1987: 17). 
b. ha-sol ha-fer

CL.ha-shirt AGr.ha-white

'white shirts'

Guñaamolo, Sauvageot 1987: 18

(15) a. katama ka-wayi

riverside AGR.CV-wide

'large rice field'

(Guñaamolo, Sauvageot 1967: 232)

b. katama-ã ka-wayi-ẽ

riverside-PL AGR.CV-wide-PL

'large rice fields'

(Guñaamolo, Sauvageot 1967: 232)

(16) a. sahri in-no

village DEM-AGR

'this village'

(Guñaamolo, Sauvageot 1967: 232)

b. sahri-ẽ a-wuri-ẽ

village-PL AGR-long-PL

'long villages'

(Guñaamolo, Sauvageot 1967: 232)

It is the analysis of the Type II nouns, which roughly coincides with agreement type 2a in my account, that has sparked the debate about phonological copying and its theoretical implications described in the introduction. The first syllable of these nouns is claimed to be copied onto agreement targets. For a summary of Sauvageot's agreement types see Table 3.

Table 3: Summary of Sauvageot's agreement and noun types.

\begin{tabular}{lll}
\hline $\begin{array}{l}\text { Prefixed nouns } \\
\text { Prefixless } \\
\text { nouns. Type I: }\end{array}$ & $\begin{array}{l}\text { Singular and } \\
\text { Plural: }\end{array}$ & Prefixed \\
& Plural: & $\begin{array}{l}\text { CV onset copied on agreement target as prefix. (only when } \\
\text { onset resembles existing NC marker) } \\
\text { CV onset copied on agreement target as prefix plus nasalised } \\
\text { vowel suffix according to rules of vowel harmony. }\end{array}$ \\
$\begin{array}{c}\text { Prefixless } \\
\text { nouns. Type II: }\end{array}$ & $\begin{array}{l}\text { Singular: } \\
\text { default agreement prefix a- or suffix -no, depending on target } \\
\text { default agreement prefix a- or suffix -no, depending on target } \\
\text { plus suffixed nasalised vowel according to rules of vowel } \\
\text { harmony, marking plurality }\end{array}$ \\
\hline
\end{tabular}




\section{Evaluation of phonological agreement-copying}

In Section 4.1 I will identify problematic aspects inherent in Sauvageot's account of the Baïnounk Guñaamolo noun class system and then deal with a series of analytical problems connected to the agreement-copying hypothesis in Section 4.2, drawing on data from Baïnounk Gubëeher and Baïnounk Guñaamolo. I show that the observed characteristics of the noun class and agreement prefixes do not conform to what would be expected if the agreement patterns of nouns with suffixed plural and alliterative agreement were indeed instances of agreement-copying as suggested by Sauvageot.

\subsection{Review of Sauvageot's Baïnounk Guñaamolo data}

Sauvageot's sketch of the noun class system of Baïnounk Guñaamolo is the first, and has been until recently, the only description of a grammatical domain of any Baïnounk language. It is therefore not surprising that in addition to providing only few examples, some points, which are crucial in judging whether or not phonological agreement-copying is operating in Baïnounk Guñaamolo, remain unclear in his account: (1) There is no information on which prefixes exactly engage in 'agreement-copying' (2) There is no information on which percentage of plural-suffixed-nouns have 'default agreement' and which have 'agreement-copying'9 (3) There is conflicting information as to whether the presumably copied CV onsets are part of the stem or not.

The following three examples adapted from Sauvageot and listed here in (17)-(19) are the only evidence provided for 'phonological agreement-copying'. ${ }^{10}$ According to Sauvageot's analysis the onsets ka-, fu- and da- (ja- in my transcription) are considered part of the noun stem not prefixes and the agreement on the modifiers as phonological copying of the onset onto the agreeing target.

9 1995: 137) quotes Sauvageot on his statement that one fourth of 800 nouns are prefixless as evidence for the productivity of the stipulated LAC pattern, although Sauvageot never states how many of these 'prefixless nouns' actually have alliterative agreement.

10 Sauvageot has not glossed his examples. The glosses are added by me, according to Sauvageot's analysis. AGR.CV stands for agreement with the initial CV-onset. 
(17) a. katama ka-wayi

riverside AGR.CV-wide

'large rice field ${ }^{11}$,

(Guñaamolo, Sauvageot 1967:232)

b. katama-ã ka-wayi-ẽ

riverside-PL AGR.CV-wide-PL

'large rice fields'

(Guñaamolo Sauvageot 1967:232)

(18) a. fonare fu-leri

riddle AGR.CV-difficult

'difficult riddle'

(Guñaamolo, Sauvageot 1987: 19)

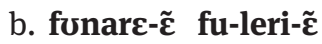

riddle-PL AGR.CV-difficult-PL

'difficult riddles'

(Guñaamolo, Sauvageot 1987: 19)

(19) a. dapənู-ว də-rã

grass-DET AGR.CV-which

'which grass'

(Guñaamolo, Sauvageot 1967: 232)

b. dapon-̃̃ da-məkila-ã ingi ka-nak-ã

grass-DET:PL AGR.CV-five-PL and AGR.ka-two-PL

'seven blades of grass'

(Guñaamolo, Sauvageot 1967: 232)

The examples illustrating the agreement of katama in the singular (17a) and katama-ã in the plural (17b) are actually counterexamples to agreement-copying for several reasons. First of all, ka- is attested as a noun class prefix in Guñaamolo and other Baïnounk varieties, on locatives and verbal nouns. It seems implausible that a marker that is used for derivation in other areas of the NC system should be considered copied. The prefix ka- is attested in Baïnounk Guñaamolo for deriving verbal nouns from stems denoting events as shown in the following examples from Sokhna Bao-Diop (p.c.): the stem bos

11 The term katama can refer to the river as a body of water, the wetlands around a river and also to ricefields which are located in these wetlands. I have glossed it as 'riverside' but kept Sauvageot's gloss of rizière in the English translation 'rice field'.' 
'give birth' is nominalised as ka-bos 'to give birth/giving birth' and the stem hubun 'bury' is nominalised as ka-hubun 'to bury/burying'.

More importantly, Baïnounk Guñaamolo ka-taama 'riverside' is a loan from a Jóola language (cf. Jóola Kujireray ka-taama 'riverside'), ka- being a frequent NC prefix attested in all Jóola languages. This can be considered an instance of borrowing the root with its prefix and assigning it to an already existing agreement class in Baïnounk Guñaamolo. There is evidence that the ka- class in Baïnounk Guñaamolo as well as in Baïnounk Gubëeher and in Kobiana accommodates mainly loans from various Jóola languages or Manjaku, languages where the noun class prefix ka- is very frequent. Compare 1990: 27) statement on class ka- in Kobiana: "kaN-. Singulier. Peu de termes et ils sont souvent suspects d'emprunts [translation by the author : kaN-. Singular. few items and often suspected of being loans]".

The noun ja-poñ 'grass' (in Sauvageot's transcription: daponn) is a plural form of gu-poñ 'grass' (Sokhna Bao-Diop, p.c.) and clearly prefixed; the prefix ja- is even provided as a mass plural by Sauvageot, cf. Table 2. Indeed, ja- is the noun class prefix for the plural of collections of organic material (grass, twigs, and leaves) in all major Baïnounk languages (Guñaamolo, Gubëeher, Gujaher) as shown in example (20) from Baïnounk Gubëeher.

\section{(20) a. gu-fos gungu \\ Cl.gu-grass CL.gu:DEM.PRO \\ 'this blade of grass' \\ b. ja-fos janja \\ CL.ja-grass CL.ja:DEM.PRO \\ 'this grass'}

The examples provided for the agreement behaviour of dapon 'grass' in (22) are furthermore confusing, insofar as the composite numeral seven ("five and two"), has da- agreement for the numeral 'five', and ka- agreement prefix for the numeral 'two' without any further explanation to account for this mismatch. The fact that dapon is used as a collective noun in (19a) and as a pluralised singulative in (19b) severely impairs comparability with the other examples, where singular/plural pairings are given. It would be important to compare how 'one blade of grass' is expressed and in which relation the agreement of this form stands to the plural form 'seven blades of grass'.

Another example which is treated by Sauvageot (1987: 18) as prefixless, although he does not comment on the agreement behaviour, is fa-jamen 'goat' a 
loan from Jóola Fogny e-jamen 'goat', which also has alliterative agreement as shown in (21).

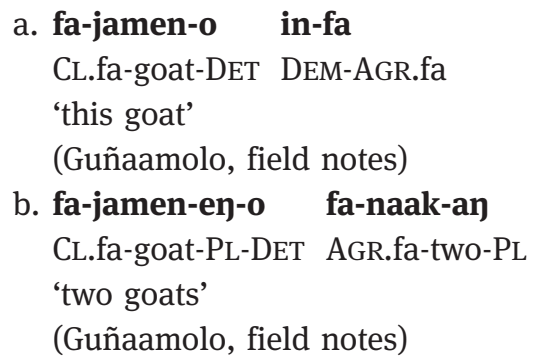

Interestingly, the stem has been borrowed, but not the original class marker e-. It is clear that the prefix fa- is certainly not copied, but that the loan has been assigned to class fa- on the grounds of the original Baïnounk word for 'goat' fabe having fa-agreement. The onset fV- of 'goat' is extraordinarily stable across all Nyun-Buy languages. As term for 'goat' Baïnounk Guñun has fébbi (Sg.)/ fébbiun (Pl.), Baïnounk Gujaher has feebi (Sg.)/ feebiën (Pl.), Baïnounk Gubelor has féébi (Sg.)/ feeébion ( $\mathrm{Pl}$.$) , Baïnounk Gubëeher has féébi (Sg.)/ féébien (Pl.) and$ Kobiana has fa-nars (Sg.)/fa-nars-a (Pl.). The Kobiana item does not seem to be a cognate of fabe, but it has fa-prefix and a suffixed plural. What has happened in Guñaamolo is that the original class associated with goat (fa-) has been kept, although a stem from another language has been borrowed. This is actually the contrary to agreement-copying; it is agreement preservation at all cost.

\subsection{Unfulfilled expectations}

Since claims of phonological agreement through copying engender assumptions about productivity, semantic and phonetic properties, prefix status and historical development of the prefixes involved, these claims will be assessed for Baïnounk Gubëeher in detail and compared to preliminary findings in Baïnounk Guñaamolo.

\subsubsection{Productivity}

If Sauvageot's hypothesis of agreement-copying was correct we would expect that a large number of agreement prefixes are compatible with plural-suffixed nouns. It should also be expected that the mechanism is productive with 
loanwords from languages without noun class prefixes. ${ }^{12}$ Neither of these expectations can be confirmed. Nouns with suffixed plurals are a common feature of all known Baïnounk languages, constituting about one fourth of all nouns in Baïnounk Guñaamolo (Sauvageot 1967; Sauvageot 1987) and about 25-30 \% in Baïnounk Gubëeher. Yet only a small proportion of these nouns have alliterative agreement and plural suffixes. The large bulk of plural-suffixed nouns trigger non-alliterative a-agreement, also labelled "default agreement" in this paper.

Table 4 shows that the number of prefixes that are found on plural-suffixed nouns in Baïnounk Gubëeher is limited. The type-frequency of nouns in each agreement class participating in this type of agreement is also quite restricted, with a total of just over $70 .{ }^{13}$ In Baïnounk Gubëeher only 318 or $26 \%$ of a total of 1,204 countable nouns in my lexicon have plural suffixes. Of those 318 nouns with suffixed plurals only 73 have alliterative agreement. This corresponds to only $6 \%$ of the total of nouns and to $23 \%$ of the plural suffixed nouns. Of the nine agreement classes occurring in this type of agreement, six have only five members or less, some of which are idiosyncratic or controversial.

Table 4: Prefixes involved in Type 2a agreement pattern in Baïnounk Gubëeher.

\begin{tabular}{lr}
\hline Agreement prefix singular and plural & Type frequency \\
\hline ba- & 30 \\
fa- & 18 \\
kan- & 9 \\
fun- & 5 \\
ja- & 4 \\
ta- & 4 \\
hu- & 1 \\
kun- & 1 \\
ho- & 1 \\
\hline
\end{tabular}

As for Baïnounk Guñaamolo, the number of prefixes with 2a agreement does not seems to be any larger. 2013: 138) quotes the prefixes ka-,ku-, ho- and fa- as triggering agreement of type 2a. Table 5 shows the NC markers participating in

12 Only very few borrowed nouns with suffixed plurals have prefixes with alliterative agreement. The ones that do tend to originate from languages which also have noun class prefixes and are better analysed as instances of noun class/agreement borrowing.

13 The 66 nouns with $\boldsymbol{a}$ - as prefix on the noun and in the agreement are excluded here, given that Sauvegeot has not included these in his class of nouns with agreement copying. 
Table 5: Type 2a agreement prefixes in Baïnounk Guñaamolo, field notes.

\begin{tabular}{|c|c|c|c|c|}
\hline Prefix & Example singular & Gloss & Example plural & Gloss \\
\hline kun- & $\begin{array}{l}\text { kuñ-ñal in-kun-duk } \\
\text { CL.kun-worm in-AGR.kun-one }\end{array}$ & $\begin{array}{l}\text { 'one } \\
\text { worm' }\end{array}$ & $\begin{array}{l}\text { kuñ-ñal-an-o ku'-lal-an } \\
\text { CL.kun-worm-PL-DEF AGR.kun-three-PL }\end{array}$ & $\begin{array}{l}\text { 'the } \\
\text { three } \\
\text { worms' }\end{array}$ \\
\hline fa- & $\begin{array}{l}\text { fa-jamen-o in-fa } \\
\text { CL.fa-goat-DEF DEM-AGR.fa }\end{array}$ & $\begin{array}{l}\text { 'this } \\
\text { goat' }\end{array}$ & $\begin{array}{l}\text { fa-jamen-en-o fa-nak-an } \\
\text { CL.fa-goat-PL-DEF AGR.fa-two-PL }\end{array}$ & $\begin{array}{l}\text { 'the two } \\
\text { goats' }\end{array}$ \\
\hline ka(n)- & $\begin{array}{l}\text { ka-rafa in-kën-duk } \\
\text { CL.ka-bottle in-AGR.ka-one }\end{array}$ & $\begin{array}{l}\text { 'one } \\
\text { bottle' }\end{array}$ & $\begin{array}{l}\text { ka-raf-an ka-nak-an } \\
\text { CL.ka-bottle-PL AGR.ka-two-PL }\end{array}$ & $\begin{array}{l}\text { 'two } \\
\text { bottles' }\end{array}$ \\
\hline ba- & $\begin{array}{l}\text { bë-gid-o im-bën-duk } \\
\text { CL.ba-girl-DEF in-AGR.fa-one }\end{array}$ & $\begin{array}{l}\text { 'one } \\
\text { girl' }\end{array}$ & $\begin{array}{l}\text { bë-gid-en-o ba-nak-an } \\
\text { CL.ba-girl-PL-DEF AGR.ba-two-PL }\end{array}$ & $\begin{array}{l}\text { 'the two } \\
\text { girls' }\end{array}$ \\
\hline fun- & $\begin{array}{l}\text { fun-jongolor-o fun-de-no } \\
\text { CL.fun-snail-DEF AGR.fun-big-DEF }\end{array}$ & $\begin{array}{l}\text { 'the big } \\
\text { snail' }\end{array}$ & $\begin{array}{l}\text { fun-jongolor-on-o fun-nak-an } \\
\text { CL.fun-snail-PL-DEF AGR.fun-two-PL }\end{array}$ & $\begin{array}{l}\text { 'the two } \\
\text { snails' }\end{array}$ \\
\hline ho- & $\begin{array}{l}\text { honj in-ho } \\
\text { thing(CL.ho) DEM-AGR.ho }\end{array}$ & $\begin{array}{l}\text { 'this } \\
\text { thing' }\end{array}$ & $\begin{array}{l}\text { honj-on ho-nak-an } \\
\text { thing(CL.ho) AGR.ho-two-PL }\end{array}$ & $\begin{array}{l}\text { 'two } \\
\text { things' }\end{array}$ \\
\hline
\end{tabular}

2a agreement I have elicited in Baïnounk Guñaamolo. It is possible that more do exist on rare items in both languages which have not yet been detected.

The number of agreement prefixes triggering type $2 \mathrm{a}$ agreement is thus quite limited, with only six prefixes that occur more than marginally. The nouns with this agreement behaviour are thus far away from constituting an almost indefinitely extendable open class both in Baïnounk Gubëeher as well as in Baïnounk Guñaamolo.

As to the expectation to find large amounts of loanwords with plural suffixes and alliterative agreement, in Baïnounk Gubëeher only very few loans obtained from Kriolu, French, Mandinka or Wolof have alliterative agreement (see examples [22] and [23]). The vast majority of loans which pluralise using the suffix - Vn trigger default agreement in a-, irrespective of the noun's onset, which is the default strategy for the integration of loans. If at all, loanwords partaking in agreement type $2 \mathrm{a}$ are borrowed from other noun class languages, mostly from Jóola languages, which have noun class prefixes themselves.

\subsubsection{Phonetic bias}

If alliterative agreement on plural-suffixed nouns was indeed purely phonologically conditioned copying of a noun's CV onset, Baïnounk noun class prefixes would constitute an open class that can and would have been extended to include all $\mathrm{CV}$ onsets found in the language and those that enter the language through loanwords. As Table 6 shows this is not the case. We do not find any prefixes of this type with phonemes that are not attested for paired prefixed 
Table 6: Phonetic distribution of agreement prefixes in Baïnounk Gubëeher, with the prefixes participating in $2 a$ agreement in plain face.

\begin{tabular}{llllll}
\hline & a & i & u & e & o \\
\hline / & a & i/in & u & e & \\
g & & & gu & & \\
b & ba & bi & bu & & \\
m & & min & mun & ko 'DIM' \\
s & & si/sin & & ño 'DIM' \\
k & ka/kan & & kun & \\
$\tilde{n}$ & ñan & & & \\
r & ran & & & \\
p & & pi & & \\
f & fa & & fun & \\
t & ta & tin & & \\
d & da & di/din & & \\
h & ha & & hu & \\
j & ja & ji & & \\
n & not attested & & & \\
$\mathrm{N}$ & & & & \\
C & & & & \\
L & & & & \\
\hline
\end{tabular}

noun classes as well. Both in prefixed agreement and in the alliterative agreement of plural-suffixed nouns, prefixes with the vowels /e/ and /o/ are marginal. Likewise, there are no attestations at all in either group of prefixes of prefixes containing /n/, /n/, /c/ or /1/. There remain many gaps of potential CV combinations that are not attested as noun class prefixes.

Sauvageot himself tones down his earlier claims (see Sauvageot [1967: 232]) about phonological agreement-copying considerably. In his later account of nominal classification in Baïnounk Guñaamolo he states that

la syllabe initiale du substantif étant de la forme CV et dans la mesure où elle peut être plus ou moins identifiée à l'un des classificateurs de la langue, est susceptible de jouer le rôle de marque de classe affectant ainsi le ou les termes régis [translation by the author, italics added : the initial syllable of the noun of the form $\mathrm{CV}$, provided it can be more or less associated with one of the class markers of the language, can potentially take the function of class marker and trigger agreement on dependent targets] (Sauvageot 1987: 18f).

If the CV-onset has to fulfil certain criteria before being eligible to be used as an agreement-prefix we are not dealing with phonological copying of stem initial 
segments but rather with reanalysis of an onset as an already existing noun class prefix. Loan integration on the basis of phonological criteria does neither have the status of extreme typological rarity nor the theoretical implications of agreementcopying. Phonological integration of loanwords is attested as a productive strategy for other noun class languages (see Demuth 2000 for data on Sesotho) and some examples are found in Baïnounk languages as well. Compare the treatment of the loan karaafa 'bottle' from Kriolu karafa 'bottle' into Baïnounk Gubëeher (22) and into Baïnounk Guñaamolo (23).

a. ka-raafa kë-këënduk

CL.ka-bottle AGR.ka-one

'one bottle'

b. ña'-raafa ñan-nak

CL.ñan-bottle AGR.ñan-two

'two bottles'

\section{(23) a. ka-raafa in-kën-duk}

CL.ka-bottle ?-AGR.ka-one

'one bottle'

b. ka-raaf-an ka-naak-an

CL.bottle-PL AGR.ka-two-PL

'two bottles'

The integration of the loan karaafa 'bottle' into the NC system of both Baïnounk languages is phonological; whereas in Baïnounk Gubëeher the noun karaafa 'bottle' is assigned to the paired prefixed classes kan-/ñan-, in Baïnounk Guñaamolo it is pluralised with the suffix and has 2a agreement.

If the borrowed noun comes from a NC-prefix language which is in close contact, like the various Jóola languages for Baïnounk Guñaamolo and Baïnounk Gubëeher, speakers are familiar with what constitutes a noun class prefix in that language and can either keep it and borrow the item along with its noun class, if there is an identical or similar prefix in the language or change the prefix to one that is more suitable for semantic reasons.

\subsubsection{Semantic bias}

Nouns with an agreement-type 2a pattern are mostly animate, with a large proportion of animals (see Table 7; Cobbinah 2010; Cobbinah 2013; Cobbinah and Friederike 2014). This in itself does not invalidate the agreement-copying 
Table 7: Agreement 2a and semantics in Baïnounk Gubëeher.

\begin{tabular}{ll}
\hline Agreement class & Semantics \\
\hline kan- & mixed, fish, locations \\
fa- & many animals, many fish \\
fun- & fish and other sea animals \\
ta- & many animals \\
ba- & mixed, animals \\
a- & all insects \\
\hline
\end{tabular}

hypothesis, but it is another piece of evidence against purely phonetic agreement-copying, since certain semantic classes are more likely to be found among 2a nouns.

\subsubsection{Prefix status and integration into the system}

The agreement-copying hypothesis hinges crucially on the question of prefix status of the disputed CV-onsets. If, as Sauvageot claims and Dobrin pursues, the CV-onsets of the presumed agreement-copying nouns (type 2a) are integral parts of the stem, they should not be substitutable by other prefixes, e.g. derivational prefixes such as diminutive, augmentative or a collective plural prefix.

For a number of nouns treated as prefixless by 1967: 230), he provides alternative plural forms or diminutives elsewhere in the document, where the supposed CV onset, although analysed as part of the stem, is substituted by another prefix (see Table 8). Maintaining the assumption that these items are prefixless, he states that "[1]a présence d'un préfixe de classe est susceptible d'engendrer des phénomènes d'aphérèse, amputant de la sorte le lexème, ce qui ne manque pas de rendre parfois l'analyse en monèmes fort délicate et

Table 8: Substitutability of prefixes of plural-suffixed nouns in Baïnounk Guñaamolo.

\begin{tabular}{|c|c|c|c|c|c|}
\hline Gloss & Singular & Plural & Collective & Diminutive (ko-) & Source \\
\hline ‘arc’ & funagen & funagen- $\tilde{\varepsilon}$ & ti-nag $\varepsilon n-\tilde{\varepsilon}$ & (not provided) & (Sauvageot 1967: 230) \\
\hline 'cow' & ahay & ahay-ã & ti-hay-ã & (not provided) & (Sauvageot 1967: 230) \\
\hline 'horse' & dibon & dibon-õ & ti-bon-õ & (not provided) & (Sauvageot 1967: 230) \\
\hline 'girl' & bë-gid & bë-gid-ën & l & kó-gid & Sokhna Bao-Diop,p.c. \\
\hline 'fish' & fa-kat & fa-katano? & ja-kat & ko-kat & Sokhna Bao-Diop,p.c. \\
\hline 'bird' & fa-tono & $?$ & $?$ & ko-tono & Sokhna Bao-Diop,p.c. \\
\hline
\end{tabular}


incertaine [The presence of a class prefix can cause truncation phenomena, thus amputating the lexeme, as a result of which the distinction of morphemes may become a highly delicate and uncertain matter] (Sauvageot 1967: 230).” If any other criteria than substitutability from the stem are used for determining prefix status it does not become clear which ones these could be. Considering substitutability as evidence for prefix status is more straightforward in this case than assuming that a CV onset is first copied onto agreement and then "amputated", when derived into a diminutive or collective class. More Baïnounk Guñaamolo examples provided by Sokhna Bao-Diop (p.c., dictionary database) show that other 2a prefixes in Guñaamolo are substitutable as well (Table 8).

The same objections can be made using data from Baïnounk Gubëeher. As has been shown for Guñaamolo in Table 8, it is equally true for Baïnounk Gubëeher that most of the prefixes which engage in alliterative agreement and attach plural suffixes can be substituted by other prefixes, be it a diminutive an augmentative or a collective plural (cf. examples [6]-[7] from Gubëeher, here repeated as [24], and 10]).

(24) a. bë-kér

CL.ba-chicken

'chicken'

b. bë-kér-én

CL.ba-chicken-PL

'chickens'

c. ko-kér

CL.ko-chicken

'small chicken'

The fact that the class of prefixes claimed to be involved in phonological copying by Sauvageot and Dobrin (of agreement type 2a) are systematically found in other contexts, e.g. as adverbial noun classes, for derivational purposes or in paired, prefixed patterns with other nouns speaks against the validity of this hypothesis. Agreement-copying implies that the copied agreement prefixes enlarge the system by adding hitherto unattested agreement patterns and that their only purpose is the provision of agreement morphology for nouns that lack noun class morphology. As a consequence, these prefixes should not be expected to be well-integrated in the system, having derivational functions and occurring elsewhere in the system.

Some of these prefixes are well integrated into the NC system, in that they occur as prefixes for derivational purposes, for the formation of infinitives or other types of verbal nouns or with an absolute use, i.e. "attached to a 
pronominal base conveying temporal, local or circumstantial meaning in absence of a head noun" (Cobbinah 2013: 351), as shown in example (25) where the agreement prefix ka- attached to the relative marker conveys local semantics: kë-ni 'the place where'. In the same way the prefix fa- when combined with the relative marker conveys temporal semantics: fë-ni 'at the time when'. For more examples of the use of these and other noun class markers in headless constructions with modifiers see Cobbinah (to appear).

(25) a-wor na pe a ko-jund kokoon kë-ni

3-throw there all PREP CL.ko-hole AGR.ko:DEM.DIST AGR.ka-REL

hu-naan huhoon ë-gu-ne

Cl.hu-thing AGR.hu:DEM.DIST 3-be-SUB

'He throws all that there in the small hole, where the thing is.'

(Gubëeher, Cobbinah 2013: 354)

The derivation of infinitives and verbal nouns from roots which are usually used in verbal syntactic frames involves a large number of the available noun class prefixes in Baïnounk Gubëeher, among which are many of those engaging in alliterative and plural-suffixed agreement, as shown in Table 9.

Table 9: Infinitives in Gubëeher.

\begin{tabular}{lll}
\hline Gloss & Root & Infinitive \\
\hline 'to fish with arrows' & yah & ta-yah \\
'to sew' & luf & ba-luf \\
'to live' & bëg & këm-bëg \\
\hline
\end{tabular}

Three of the prefixes also occur in regular purely prefixed, paired or triadic paradigms, which further supports my analysis that these are truly prefixes and not merely CV-onsets of noun stems when triggering alliterative agreement, cf. Table 10 for a summary.

\subsection{Borrowing of the plural suffix from Mandinka}

Sauvageot's analyses of the NC system of Guñaamolo are to some extent based on the assumption that the Baïnounk plural suffix $-\mathbf{V} \mathbf{n}^{14}$ is borrowed from Mandinka, a language in close contact with Guñaamolo which has no noun

14 Its form is $-\boldsymbol{V} \boldsymbol{\eta}$ in all known Baïnounk languages and -a in Kobiana (Doneux 1990). 
Table 10: Summary: Prefixes involved in 2a agreement in other paradigms and functions in Baïnounk Gubëeher.

\begin{tabular}{lllll}
\hline $\begin{array}{l}\text { Agreement } \\
\text { class }\end{array}$ & $\begin{array}{l}\text { Attested in purely } \\
\text { prefixed } \\
\text { paradigms }\end{array}$ & $\begin{array}{l}\text { Prefix } \\
\text { substitutable }\end{array}$ & $\begin{array}{l}\text { Attested on } \\
\text { infinitives }\end{array}$ & Other \\
\hline ka(n)- & Yes (kan-/ñan-) & for some & Yes & $\begin{array}{l}\text { locative semantics relative and } \\
\text { demonstrative pronouns and } \\
\text { nouns } \\
\text { temporal semantics with some } \\
\text { fa- }\end{array}$ \\
No & for some & No & modifiers \\
fun- & No & for some & No & $/$ \\
ta- & No & Unknown & Yes & $/$ \\
ba- & Yes & for all & Yes & $/$ \\
a- & Yes & for some & No & $/$ \\
\hline
\end{tabular}

classes but has a plural suffix of the form -lu. The assumption goes that this allegedly borrowed plural, in conjunction with agreement-copying, has been used to accommodate loans from classless languages into the noun class system of Guñaamolo. This hypothesis of the origin of the plural suffix in Baïnounk languages is hardly convincing in light of the fact that suffixed plurals have arisen internally in many Atlantic languages such as Fula. They are also attested in several Mel languages, which according to new classifications are not considered as part of the Atlantic family from a genealogical point of view any more but might still share areal traits with Atlantic languages. Moreover, plural suffixes occur in all Nyun-Buy languages and it cannot be assumed that the speakers of all of these varieties have been in close contact with Mandinka. I agree on this point with Voisin (2015b) who argues on the basis of evidence from Kobiana that suffixed plurals must predate the split between Kobiana and the Baïnounk languages. Baïnounk Gubëeher is currently spoken in an area west of the furthest reach of Mandinka expansion and has only few Mandinka loans, and Kobiana is deeply integrated culturally and linguistically into the surrounding Manjaku culture. Considering the significant lexical and grammatical differences between Kobiana/Kasanga on the one hand and the Baïnounk languages on the other hand, the two subgroups of Nyun-Buy must have already diverged by the time of the first contact with Mandinka, less than a millennium ago. The rate of cognates between Baïnounk languages and Kobiana/Kasanga is calculated as little as $36 \%$ by 1990: 87) and between $60 \%$ and $70 \%$ for the major Baïnounk languages. Neither independent innovation of plural suffixes in each of the Nyun languages nor independent acquisition through borrowing from Mandinka is a serious possibility considering the high degree of similarity of the 
noun class systems of the Nyun languages. It would be hard to explain how plural suffixes of a similar phonetic shape on the same noun stems arose independently in each of the Nyun languages through contact with Mandinka. Furthermore, the Mandinka plural suffix -lu does not have formal similarity with the Baïnounk Gubëeher and Baïnounk Guñaamolo plural suffix -Vn or the Kobiana plural suffix -a (see Voisin 2015b for a discussion of the Mandinkaorigin of the Nyun plural suffix).

\section{Alternative analysis}

The preceding sections have presented detailed evidence which speaks against the assumption of phonological agreement-copying in Baïnounk Gubëeher and Baïnounk Guñaamolo. Due to the structural similarities of noun class systems within the Nyun-Buy group of languages it can be concluded that phonological agreement is not active in any of the languages. A Mandinka origin of plural suffixes in Nyun-Buy languages is improbable.

In the following sections (based on a preliminary version presented in Cobbinah 2010), I address question of the origin and evolution of suffixed plural in Nyun-Buy languages, starting with the semantic connotations of plural suffixes in Baïnounk languages (Section 5.1). Several propositions for a potential origin of suffixed plural morpheme are summed up in Section 5.2. It has been tentatively suggested that plural suffixes might be related formally to either associative plurals (Creissels to appear) or plural marking in verbal inflection (Cobbinah and Friederike 2014; Voisin 2015b). Whether or not this is tenable, the high concentration of animates as well as the collective connotations of plural suffixes make it conceivable that plural suffixes have started out as collective or a special marker for animates high on the animacy hierarchy, such as terms denoting family members. A scenario of such a process - spread of suffix marking from animates to the entire system - has been proposed by Childs (1983) in search of an explanation for the development of suffixed noun class markers in the Mel languages (Section 5.3). Whether or not a parallel process has occurred in Nyun-Buy, the class of nouns with plural suffixes has had a considerable boost in numbers due to the heavy influx of loans from classless languages that have been integrated into Baïnounk languages mostly as prefixless and with suffixed plurals (Section 5.4). Synchronic data from Baïnounk Guñun (Quint 2015) and Baïnounk Gujaher (Lüpke to appear) show that a restructuring of the noun class systems towards the development of animacy agreement, is on-going in these languages, accompanied by high levels of variation. 


\subsection{Semantics of plural suffixes}

Apart from marking plural number, the plural suffixes attested in Nyun-Buy languages also have semantic connotations. So far, animacy and collective semantics have been identified as semantic parameters relevant to plural suffixes. It has been shown for some Nyun-Buy languages that plural suffixation is clearly correlated with animacy, explicitly in Cobbinah (2013) and Cobbinah and Lüpke (2014) with data for Baïnounk Gubëeher and Baïnounk Gujaher. This observation is supported by new data collected by 2015a, 2015b) on Kobiana. Similar observations have been made by Quint (2015: 441) on Baïnounk Guñun of Djifanghor, where 52 out of 80 nouns with suffixed plurals denote animals. Basso Marques (1947: 882) also observes for the related languages Kobiana and Kasanga from the Buy branch of Nyun-Buy, that the plural-suffixed classes contain mainly animals. Leaving loanwords aside, living beings are overrepresented in the class of nouns that pluralise using a suffix compared to those that pluralise by commutation of noun class prefixes. In Baïnounk Gubëeher, we find almost all core denotations for family members, the associative plurals for proper names, and a large proportion of nouns denoting animals among those nouns which pluralise using the suffix. The most important domestic animals, all insects, many fish and birds, all animals prefixed with a- and ji- have suffixed plurals (see Table 11). Out of 195 terms in my lexicon denoting animals, 135 or $69 \%$ have suffixed plurals whereas the overall proportion of nouns with plural suffixes would be expected to be much lower, around 25-30\% (in my lexicon $26 \%$ or 318 plural-suffixed out of 1,204 countable nouns). Even

Table 11: Animate nouns and suffixed plurals in Baïnounk Gubëeher (from Cobbinah and Lüpke, 2014: 212).

\begin{tabular}{|c|c|c|c|c|c|}
\hline \multirow[t]{2}{*}{ Domain } & \multicolumn{4}{|c|}{ Examples Baïnounk Gubëeher } & \multirow[t]{2}{*}{$\%$ suffixed in domain } \\
\hline & Singular & & Plural & & \\
\hline KINSHIP & $\begin{array}{l}\text { bëëb } \\
\text { asom }\end{array}$ & $\begin{array}{l}\text { 'father' } \\
\text { 'maternal aunt' }\end{array}$ & $\begin{array}{l}\text { bëëb-ën } \\
\text { asom-on }\end{array}$ & $\begin{array}{l}\text { 'fathers' } \\
\text { 'maternal aunts' }\end{array}$ & $\begin{array}{l}30 \% \\
{[7 / 21]}\end{array}$ \\
\hline NAMES & $\begin{array}{l}\text { Eko } \\
\text { Saaña }\end{array}$ & $\begin{array}{l}\text { 'Eko [first name]' } \\
\text { 'Sagna [clan } \\
\text { name]' }\end{array}$ & $\begin{array}{l}\text { Eko-n } \\
\text { Saaña-n }\end{array}$ & $\begin{array}{l}\text { 'Eko and his friends } \\
\text { 'the Sagna families' }\end{array}$ & productive \\
\hline HUMAN & $\begin{array}{l}\text { bëjid } \\
\text { jidef }\end{array}$ & $\begin{array}{l}\text { 'girl' } \\
\text { 'old person' }\end{array}$ & $\begin{array}{l}\text { bëjid-ën } \\
\text { jidef-en }\end{array}$ & $\begin{array}{l}\text { 'girls' } \\
\text { 'old persons' }\end{array}$ & $\begin{array}{l}47 \% \\
{[15 / 32]}\end{array}$ \\
\hline ANIMAL & $\begin{array}{l}\text { bëkér } \\
\text { jifek } \\
\text { balaap }\end{array}$ & $\begin{array}{l}\text { ‘chicken' } \\
\text { 'pig' } \\
\text { 'pigeon }\end{array}$ & $\begin{array}{l}\text { bëkér-ën } \\
\text { jifek-en } \\
\text { balaap-an }\end{array}$ & $\begin{array}{l}\text { 'chickens' } \\
\text { 'pigs' } \\
\text { 'pigeons' }\end{array}$ & $\begin{array}{l}69 \% \\
{[135 / 195]}\end{array}$ \\
\hline
\end{tabular}


assuming the possibility that my dictionary is not balanced, it is more likely to over-represent botanical items rather than animals due to the nature of my research on ethno-botany as part of an interdisciplinary research team. The vast majority of nouns from the botanical domain are purely prefixed. Similar ratios of nouns with plural suffixes to the one in my database are reported for other Baïnounk languages, Quint (2015) quotes 99 nouns with plural suffixes out of a total of 381 for the closely related Baïnounk Guñun and Sauvageot (1967, 1987) 25-30 \% for Baïnounk Guñaamolo (see Section 3). Conversely the 131 animals make up $38 \%$ of all 344 plural-suffixed nouns and are thus overrepresented as a domain within this morphological group, considering that animal terms only amount to $14,9 \%$ of the total of the 1,204 nouns with a singular plural distinction. When all animates are counted, i.e. including terms for humans and supernatural beings, the proportion is even higher, with 163 out of 344 nouns with plural suffixes, or $47 \%$, denoting animates. This is substantial, especially when considering that most of the remaining items are loanwords which are per default integrated into paradigms with plural suffixes.

As already stated in Cobbinah and Lüpke (2014), the plural suffix has, apart from its pluralising function, collective connotations. In Baïnounk Gubëeher, the plural suffix is a productive morpheme in forming associative plurals. It can be attached to any first name or family name and when attached to a first name it is used when referring to the extended network, peer group or family of that person. In combination with a family name, all the families bearing that name are grouped into one collective entity. Not all Baïnounk languages, for instance Baïnounk Gujaher, allow plural suffixes on personal names. This does not invalidate the hypothesis, as the existence of associatives is an optional feature that might not have been retained across the group, or replaced by other strategies of referring to groups of people.

The plural suffix does not occur exclusively in complementary distribution with prefixed plural marking. Baïnounk Gubëeher has nouns that in addition to pluralising with prefixed noun class morphology can add a plural suffix to the already pluralised forms, resulting in double plural marked forms, as shown in Table 12. Double marking has been recorded for diminutives of animals, featuring the regular diminutive noun class prefix ño-, with the option of adding a plural suffix to this already pluralised form. Conclusive data on the semantics of these forms is not yet available but native speakers insist that the simple and double marked plurals encode a semantic difference. Speakers' intuitions indicate that the double marked forms have a group or a species reading. The tree terms with plural suffixes in the same table have clear collective readings, referring to groups of trees. 
Table 12: Double marked plurals in Baïnounk Gubëeher.

\begin{tabular}{|c|c|c|c|}
\hline Gloss & $\begin{array}{l}\text { Prefixed } \\
\text { form }\end{array}$ & Gloss & $\begin{array}{l}\text { Prefixed and suffixed } \\
\text { form }\end{array}$ \\
\hline $\begin{array}{l}\text { 'little goats' } \\
\text { 'birds' }\end{array}$ & $\begin{array}{l}\text { ño-féébi } \\
\text { ja-puul }\end{array}$ & $\begin{array}{l}\text { '(group of?) little goats' } \\
\text { '(flock of?/ various species of ?) } \\
\text { birds' }\end{array}$ & $\begin{array}{l}\text { ño-féébi-en } \\
\text { ja-puul-on }\end{array}$ \\
\hline $\begin{array}{l}\text { 'mango trees' } \\
\text { 'annona trees' } \\
\text { 'mangrove } \\
\text { plants' }\end{array}$ & $\begin{array}{l}\text { mu-mangu } \\
\text { mun-taat } \\
\text { mu'-rac }\end{array}$ & $\begin{array}{l}\text { 'group of small mango trees' } \\
\text { 'group of annona trees' } \\
\text { 'extension of mangrove bushes' }\end{array}$ & $\begin{array}{l}\text { ja-mangu-on } \\
\text { ba-taat-an } \\
\text { ba-rac-an }\end{array}$ \\
\hline
\end{tabular}

A number of kinship terms are also characterised by doubly marked plurals (Table 13). Some of these forms are the regular and only available plural forms, as with the terms for siblings. At least for the forms of 'woman/wife' a semantic distinction between the two plural forms can be stipulated. The simple marked plural in-dikaam is the regular form used to refer to women in the plural either individually or collectively. The form in-dikaam-an has occurred in the corpus with clear collective semantics, when the totality of an actor's wives in a polygamous household was referred to.

Table 13: Double marked kinship terms in Baïnounk Gubëeher (Cobbinah and Friederike 2014:213).

\begin{tabular}{llll}
\hline Gloss & Singular & Purely prefixed plural & Prefixed and suffixed plural \\
\hline 'different sex sibling' & u-lina & $/$ & a-lina-n \\
'same sex sibling' & u-dëën & $/$ & in-dëën-ën \\
'friend' & u-ñaam & ñan-ñaam & in-ñaam-an \\
'woman/wife' & u-dikaam & in-dikaam & in-dikaam-an \\
\hline
\end{tabular}

The high concentration of animates and animals among the nouns that pluralise using the suffix as well as the collective semantics attested at least for Baïnounk Gubëeher serve as basis for the hypotheses looking at a possible origin of the plural suffix marker presented in the following section.

\subsection{Origins of plural suffixes}

Nothing can be said with certainty as to the origins of plural suffixes in NyunBuy languages. As they function outside of the noun class system, they cannot 
be considered noun class morphemes. In a language like Fula, the only Atlantic language (in the revised sense of 'Atlantic') that does have noun class suffixes, these suffixes are portmanteau morphemes conveying information about noun class and number. In Fula, noun class is thus indicated through suffixes, whereas in Nyun-Buy the only function of the plural suffix is the expression of number. For those nouns in Nyun-Buy that use a suffix to pluralise, noun class is either conveyed separately by a prefix that is irrelevant for number marking or the affected nouns are classless and prefixless. If the Nyun-Buy suffixes are an innovation that is indeed limited to this branch of North Atlantic, there are still various possibilities for a genesis of these suffixes. They might have been borrowed, in form and function, or developed internally. In the second case the independent innovation might have been conditioned by language contact or arisen out of syntactic or morphological constraints. In any case the establishment of plural suffixes would have had to occur at a stage before the split of Nyun-Buy into Baïnounk languages on the one hand and Kobiana /Kasanga on the other hand. Otherwise it would be hard to explain how plural suffixes came to be an integral part of nominal morphology in both branches. Considering the considerable lexical and grammatical differences between the two branches of Nyun-Buy (see Doneux 1990), the split - and therefore the development of plural suffixes - must have occurred millennia ago.

Some attempts at indexing possible sources for an internally developed plural suffix have been made. It has been observed in 2014) and Voisin (2015b), that plurality in the verbal domain is marked with nasal consonants (see Table 14, thus formally similar to the plural suffix -n).

The sharing of plural morphology between the verbal and the nominal domain has been described for other language families. Mithun's (1988) chapter is a detailed study on reduplication and affixal morphology spanning plural marking on verbs and plural marking on nouns in North American languages. In some of these languages, morphemes used to form nouns with plural or distributive semantics are also used in verbal constructions encoding plural

Table 14: Nasal consonant in the verbal paradigm of Baïnounk Gubëeher (Cobbinah and Friederike 2014: 218).

\begin{tabular}{|c|c|c|c|c|}
\hline & \multirow{2}{*}{$\frac{\text { Singular }}{\text { Prefix }}$} & \multicolumn{3}{|l|}{ Plural } \\
\hline & & Prefix & & Suffix \\
\hline 1. Person & i- & $\begin{array}{l}\text { incl. } \\
\text { excl. }\end{array}$ & $\begin{array}{l}\text { i-n- } \\
\text { i- }\end{array}$ & $\begin{array}{l}-0 \\
-\min \end{array}$ \\
\hline 2. Person & u- & u- & & $-V \eta n$ \\
\hline 3. Person & a- & a-n- & & \\
\hline
\end{tabular}


number of participants or pluractionality. As is the case for many of the languages described by Mithun (1988) in this context, Baïnounk languages are characterised by high flexibility to combine lexical roots with nominal, verbal and adjectival morphology (see Cobbinah to appear). There is morphology in Baïnounk Gubëeher that is used across syntactic categories, such as the past suffix -ot, which can be used on verbs and copulas to express that the duration of an action or a state has been completed in the past and has no relevance for the present (26). In combination with possessed nouns, the suffix indicates that the relationship of possession is not valid any more (27).

\section{(26) ba-rux bë-gini u-ruh-ne a-naarin-ot \\ CL.ba-water AGR.ba-REL 2-drink-SUB 3-cold-INACT \\ 'The water you drank was cold.' \\ (Gubëeher, Cobbinah 2013: 266)}

\section{(27) Na koona-hum-ot}

DEM house-1SGPOSS-INACT

'That used to be my house'

(Gubëeher, Cobbinah 2013: 238)

Another attempt at identifying a source construction for plural suffixes involves associative plurals. It has been observed by Creissels (to appear) that suffixes with nasal consonants are attested in associative function in various Atlantic languages, particularly in Wolof and Fula (see Table 15.

Creissels (to appear) considers the option as plausible that plural marking in Nyun-Buy can be traced back to associative markers in proto-Atlantic which subsequently have spread to become compatible with nouns other than proper names. So far no attempt has been made to try to provide a specific grammaticalisation chain tracing the evolution of the (associative) items into plural morphemes in Nyun-Buy. However, both subject/object markers on verbs as well as associative morphology on nouns often have pronominal origins out of which they grammaticalise, even in languages in which there is no flexibility in the assignment of lexical roots to categories. The grammaticalisation of pronouns to person/number marking is a common process, as documented in Hopper and Traugott (2003: 15). I thank an anonymnous reviewer for pointing out that the development of associative marking from pronouns often involves a source construction using a third person plural pronoun with a person's name. In Wolof for example, an alternative way to the suffix -en for the formation of associatives is the use of the third person plural pronoun ñoom, as in ñoom Edouard (literally 'them Edouard'), to refer to Edouard and his associates. 
Table 15: Associatives in selected Atlantic languages.

\begin{tabular}{|c|c|c|c|c|}
\hline Language (Source) & Morphology & Example & Gloss & $\begin{array}{l}\text { Part of NC } \\
\text { system }\end{array}$ \\
\hline $\begin{array}{l}\text { Nalu } \\
\text { (Seidel to appear b) }\end{array}$ & $-y \varepsilon$ & Dauda-ye & $\begin{array}{l}\text { 'Dauda and his } \\
\text { friends' }\end{array}$ & yes \\
\hline $\begin{array}{l}\text { Jóola Eegimaa } \\
\text { (Sagna 2008: 109) }\end{array}$ & $-\mathbf{i}$ & $\begin{array}{l}\text { Ámbulat-i } \\
\text { jañuxuren-i }\end{array}$ & $\begin{array}{l}\text { 'Ámbulat and his } \\
\text { friends' } \\
\text { 'animal and his } \\
\text { kind' }\end{array}$ & no \\
\hline Baïnounk Gubëeher & $-\eta$ & $\begin{array}{l}\text { Saña-n } \\
\text { Klód-on }\end{array}$ & $\begin{array}{l}\text { 'the Sagna families' } \\
\text { 'Claude and his } \\
\text { equals' }\end{array}$ & no \\
\hline $\begin{array}{l}\text { Wolof } \\
\text { (Torrence 2013: 44) }\end{array}$ & -en & Jóób-en & $\begin{array}{l}\text { 'members of the } \\
\text { Diop family' }\end{array}$ & no \\
\hline $\begin{array}{l}\text { Fulfulde (= Fula) } \\
\text { (McLaughlin 2015: 436) }\end{array}$ & -Pen & $\begin{array}{l}\text { Aali-'en } \\
\text { halpulaar-'en }\end{array}$ & $\begin{array}{l}\text { 'Ali and company' } \\
\text { 'speakers of Pulaar' }\end{array}$ & no \\
\hline
\end{tabular}

If the plural suffix has evolved within Nyun-Buy as an innovation, it is reasonable to assume in either of the cases proposed as origin for plural suffixes above that a semantically or functionally constrained morpheme has expanded to convey plurality on nouns. The high proportion of animate nouns and the collective overtones associated with suffixed plurals suggest that suffixed plurals have started out as plural markers for entities high on the animacy scale. Entities are graded along a scale according to the criterion of animacy, ranging from inanimate objects to animals, human beings and possibly specific human beings like family members as most animate. The subdivisions and relevant parameters are language specific but animacy hierarchies have been shown to play a role in case marking and gender assignment (see Dahl 2000). The following section explores how animacy could have played a role in making plural suffix a productive means of pluralisation starting out as plural marker for animates and spreading to include inanimates.

\subsection{Genesis of the suffixed plurals}

Childs (1983) has proposed a model aiming to explain the development of noun class suffixes in the Mel languages in which animacy plays a major part. I present Childs' model as a potential template for the spread of plural suffixes in Baïnounk but do not imply any direct effect, through contact or genetically conditioned, of processes affecting the noun class systems in Mel languages on 
the noun class systems of Nyun-Buy languages. It is not implied either that plural suffixes in Nyun-Buy languages and noun class suffixes in Mel languages have parallels in their genesis. This is precisely because the development of noun class suffixes, as in Fula and Kisi, is usually explained through the grammaticalisation of post-posed agreeing determiners, that lose their original function and become generalised to noun class markers (Greenberg 1978; Childs 1983). Contrarily, in Nyun-Buy we are dealing with suffixes whose only function is plural marking, not class marking, and which must necessarily have evolved through a different path (see Section 5.2 for suggestions). Childs' model is nevertheless interesting in the discussion of Nyun-Buy plural suffixes, due to parallels in the role of animacy in the spread of the respective types of suffixes. In Childs' scenario Mel languages are thought to have been prefixing at an earlier stage and developed suffixes that have spread to varying extents in the languages of this group. Childs (1983) suggests animate nouns as a starting point of the spread of plural suffixes, i.e. the suffixes would initially have been used to mark plurality for nouns high up the animacy hierarchy and subsequently generalised to become the plural marking for a wider choice of nouns, in the process eroding the original prefixed system.

[t]wo general processes are at work. The first is the erosion of the functional importance and the phonetic substance of the prefix. The second is the spread of the importance of the suffix, expanding its domain from animate nouns, to plural nouns, to all nouns (Childs 1983: 27).

The spreading of plural suffixation across the whole noun class system as conceived by Childs (1983) involves three steps. In the first step, the original plural prefixes are substituted by plural suffixes. As a result, the prefixes cease to mark number distinction, become functionally bleached and in step two erode away or fuse to the noun, and in the process lose their prefix status. In step three the noun loses the agreement pattern associated with the original prefix and triggers default agreement.

The process of developing noun class suffixes in the Mel languages is hypothesised by Childs (1983) to have started with animate nouns and then spread to other semantic domains along the animacy hierarchy. As outlined in the model, the original plural prefixes in the Mel languages that have developed suffixes, have been substituted by plural suffixes. The former singular prefixes would have gradually extended to plural forms and as a result evolved into noun class prefixes independent of number marking. The singular-plural distinction has been taken over by the encroaching plural suffixes. Having lost the function of number distinction to the plural suffix, the affected prefixes keep losing other syntactic features in the process until they completely fuse 
with the stem without the remainder of any syntactic impact in terms of agreement.

Synchronic data from Baïnounk languages suggests that at least a subset of nouns have gone through a process leading from originally prefixing nouns to plural-suffixing. Different to the situation in Mel, plural suffixes in Nyun-Buy languages have never assumed the function of noun class morphology but rather contributed to neutralising noun class distinctions by eroding prefixed noun class morphology and replacing it with nothing equivalent. As shown in the first part of this paper, in Baïnounk Gubëeher and Guñaamolo a proportion of nouns with suffixed plurals have prefixes that trigger alliterative agreement (see Section 2). In Baïnounk Gujaher and Baïnounk Guñun the situation is different; close to all plural-suffixing nouns have either reverted to default marking or have innovated animacy agreement (see Cobbinah to appear for a detailed discussion of animacy agreement in Baïnounk languages and beyond), or for some speakers to default agreement (see Lüpke to appear; Quint 2015). This even concerns some nouns that are in purely prefixed paradigms like ran-/ ñan- (see Table 16). In other Baïnounk languages such as Gubëeher and Guñaamolo all items, without exception, that are in the ran-/ñan- paradigm have purely prefixed and alliterative agreement.

Table 16: Animacy agreement in Baïnounk Guñun (from Quint 2015).

\begin{tabular}{llllll}
\hline $\begin{array}{l}\text { Type } \\
\text { agreement }\end{array}$ & $\begin{array}{l}\text { Singular } \\
\text { noun }\end{array}$ & $\begin{array}{l}\text { Singular } \\
\text { agreement }\end{array}$ & $\begin{array}{l}\text { Plural } \\
\text { noun }\end{array}$ & $\begin{array}{l}\text { Plural } \\
\text { agreement }\end{array}$ & Gloss \\
\hline alliterative & rán-kub & ran & ñán-kub & ñan & 'initiation' \\
animacy & rán-fơt & a & ñán-fơt & in & 'bird species' \\
default & janéla & a & janéla-yon & a & 'window' \\
animacy & dégga & a & degga-yon & in & 'pelican' \\
\hline
\end{tabular}

Animacy agreement, prefixed with a- for the singular and in- for the plural in Baïnounk Guñun and Baïnounk Gujaher, combines the singular prefix of the default agreement and the plural prefix of the human agreement typical for Baïnounk languages. Table 16 shows how in Baïnounk Guñun of Djifanghor inanimate nouns trigger alliterative and default agreement respectively, whereas animate nouns with the same morphological structure revert to animacy-agreement prefixed with a- in the singular and in- in the plural.

The noun rón-kub 'initiation' has alliterative agreement in ran-/ñan- in Baïnounk Guñun, but the animate noun rán-fơt, the term for a bird species, 
although having the same prefixes, triggers animate agreement prefixed with a-/in- The same can be observed with the prefixless noun janéla 'window' that has default agreement prefixed with a- in the singular as well as in the plural, whereas dégga 'pelican', equally prefixless, triggers the animacy-agreement a-/in-. As a result, almost all agreement classes associated with prefixes that occur with pluralsuffixing nouns have been lost to default or animacy agreement. As seen in the examples above, even a prefixed paradigm, like ran-/ñan- can be affected by this process, losing its alliterative agreement when the noun is denoting an animal.

In Baïnounk Gujaher, the paradigm ran-/ñan- has, at least for some speakers, lost the plural prefix for animates (28) as well as for inanimates (29). Agreement for these items is subject to variation, some speakers applying default agreement (Sg: a-/ Pl: a- -n), others animal agreement (Sg: a-/ Pl: in-) and yet others alliterative agreement or a mixture of the various agreement types. This variation indicates on-going language change from prefixed noun class marking to loss of prefixation and generalisation of default or animal agreement.

(28) a. ran-guux

CL.ran-crab 'crab'

b. ran-guux-ën

CL.ran-crab-PL

'crabs'

(Gujaher, Lüpke to appear)

(29) a. ran-kub

CL.ran-initiation

'initiation'

b. ran-kub-ën

CL.ran-initiations-PL

'initiations'

(Gujaher, Lüpke to appear)

If Bühnen's (1988) data is indicative, the north-eastern moribund varieties of Baïnounk have come closest to stage three in Childs' model quoted above (see Table 17). The few nouns from this variety provided by Bühnen (1988) with their plural forms are prefixless and use the suffix $-\mathbf{n}$ for pluralisation, where other Baïnounk varieties, like Gubëeher, use commuting prefixed paradigm for cognate nouns.

The spread of plural suffixation in north-eastern Baïnounk seems to have gone so far to even affect those items whose prefixed paradigms are absolutely stable across all other known Baïnounk languages. Neither in Baïnounk Gubëeher 
Table 17: Examples from north-eastern Baïnounk, variety of Velingara, Karmanka, Kansambu (Bühnen 1988).

\begin{tabular}{|c|c|c|c|c|}
\hline \multirow{2}{*}{ Gloss } & \multicolumn{2}{|c|}{ North-eastern Baïnounk } & \multicolumn{2}{|c|}{ Baïnounk Gubëeher } \\
\hline & Singular & Plural & Singular & Plural \\
\hline 'egg’ & buni:no & buni:no-ngo & bu-niin & i-niin \\
\hline 'medicine' & sia:no & sia:no-ngo & si-han & mu-han \\
\hline ‘king’ & unamo & unamo-ngo & u-nam & ñan-nam \\
\hline 'slave’ & u-songo & ñan-sjngo & u-sóóg & ñën-sóóg \\
\hline ‘type vulture’ & gulu:no & gulurno-ngo & [no cognate] & \\
\hline 'forest' & gufaso & gufaso-ngo & [no cognate] & \\
\hline
\end{tabular}

nor in any other of the southern, western and eastern Baïnounk languages such as Guñaamolo or Gujaher do the prefixes bu-, gu- and si- ever occur with plural suffixes, they always occur with paired prefixed nouns. The north-eastern terms have clearly lost their prefixed plural forms and substituted them with prefixed plurals, extending the singular prefix to the plural form, although deprived of its relevance for the marking of number. No information about the agreement of these items is provided in the source, but in any case, the north-eastern varieties of Baïnounk possibly come close to an almost near decay of the originally prefixing noun class system. Only a few human terms in north-eastern are quoted with prefixed singulars and plurals, such as the noun for 'slave' u-songo.

The high proportion of animate nouns as well as the variable status of prefixes and their agreement used with plural-suffixing nouns establish parallels between the situation in Baïnounk languages and Childs' scenario proposed for Mel. If this is true, a core of non-loaned, plural-suffixing nouns that still preserve alliterative agreement in Baïnounk Gubëeher and Baïnounk Guñaamolo have evolved from prefixing to plural suffixed nouns in the distant past. These two Baïnounk languages would have got to stage one of Childs' (1988) model, generalising the singular prefix to the singular and plural form, and in the process deleting the original plural and expressing number with the suffix. Other Baïnounk languages, like Guñun and Gujaher, would have reached stage two, where the generalised prefix loses its agreement and prefix-status and eventually fuses with the noun. As argued above, some north-eastern Baïnounk languages have possibly expanded stage two or three across large parts of the vocabulary. In these varieties the scarce data available at this point suggests that even nouns that are strictly prefixing in all other Baïnounk languages have gone furthest in the shift from original noun class prefixes to suffixed plural marking. The following chapter further explores the influence of 
language contact and large-scale borrowing on the process of plural-suffix expansion.

\subsection{Changing systems: the shift towards suffixed plurals}

Although I disagree with Sauvageot's claim that the plural suffix has been directly borrowed from Mandinka, language contact has a heavy influence on the dynamics and the extension of plural suffixed nouns. 2001: 381) confirms that "[...] loss of agreement and subsequent petrification and loss of marking on the head noun typically arises in contact situations with languages lacking noun classes altogether, it seems". The role of language contact on noun class erosion has already been established elsewhere:

if such a system [with noun classes] were in daily contact with languages which have no such system, and indeed which have no singular/plural nominal distinction, as is the case for many Nigerian languages, speakers may develop a canonical view of language which eventually selects a system of reduced morphological specification in this area (Demuth et al. 1986: 468).

Integration of loans into a prefixless default class is of course an attractive option when nouns are borrowed from a language that does not have noun classes into one that does. The majority of loan words from non-noun-class languages (or in the case of Wolof a non-prefixing noun class language) end up in Baïnounk Gubëeher as prefixless nouns with plural suffixes and default $\mathbf{a}$-agreement ( $2 \mathrm{~b}$ agreement). The size and openness of the group of classless nouns with default agreement is definitely a result of the presence of numerous loanwords from nonprefixing languages which have been incorporated into Baïnounk Gubëeher, as in the case of caabi 'key' from Portuguese Creole cabi 'key' or through the intermediary of Wolof where the term for 'key' is cabi as well:

28 a. caabi a-munduk

key AGR-one

'one key.'

b. caabi-en a-naak-an

key-PL AGR-two-PL

'two keys'

Accordingly, contact with non-noun-class languages has encouraged the establishment of a classless group of nouns in all Baïnounk languages. The massive integration of loans from classless languages has then created a 
substantial proportion of nouns outside the noun class system, encouraging further erosion of the original prefixed system. In the case of the Baïnounk languages, the impact of language contact on the spread of suffixed plurals to the detriment of singular classes lies in the fact that the integration of large numbers of nouns from Mandinka, French, Wolof and Kriolu into the prefixless class with default agreement has impacted the balance of the system, which had been predominantly prefixing, to a system where, due to the large amount of prefixless loanwords, suffixation has become almost equally dominant.

The intensity and direction of contact induced change probably depends on external factors such as the grammatical properties of culturally dominant contact languages and the concentration of speakers in a specific area. All Baïnounk languages are spoken in small communities with only few thousand or even hundreds of speakers and by highly multilingual individuals and therefore susceptible to contact induced language change. This might manifest in different ways though, depending on the properties of the main contact languages. Although heavily exposed to non-noun-class languages like Kriolu, Mandinka or French, the populations speaking Baïnounk Guñaamolo, Baïnounk Gubëeher and Baïnounk Gubelor are culturally closely integrated into Jóola speaking societies. The intense contact with Jóola languages, which have large noun class systems themselves, might counter noun class erosion through heavy mutual borrowing which solidifies and even potentially increases the noun class inventory. Speakers of Baïnounk Guñun and Baïnounk Gujaher predominantly live in areas where the culturally dominant languages are Mandinka and Kriolu, which are both classless. This influence could be imagined to push these Baïnounk varieties towards adopting strategies that erode prefixation and alliteral agreement and steer them towards default or animacy agreement.

The most affected Baïnounk languages in terms of prefix erosion and spread of non-alliterative agreement seem to be the ones that are most fragmented in terms of speaker concentration and therefore under heavy pressure from languages of the people they are cohabiting with. Although the individual situations where Baïnounk Gujaher, Baïnounk Guñun of Djifanghor and the north-eastern Baïnounk varieties are presumably spoken are quite different in detail, these areas have in common a quite low concentration of Baïnounk speakers, even though the area covered may be large. This concentration could be argued to facilitate the maintenance of a very large and intricate noun class system with many idiosyncrasies, as the frequency of using these forms is higher than in a more scattered speech community, where other languages dominate, even in everyday situations. In the northern and north-eastern areas (around Sedhiou and in the Casamance/ Gambia borderland), Baïnounk has been almost completely replaced by Mandinka 
in all domains and is at best remembered by old people (Denis Creissels, p.c.). Incorrect learning or imprecise remembering due to infrequent usage might have led to the accelerated reorganisation of the prefixed noun class system in these moribund varieties (as described in Section 5.3, by generalising a feature shared by all Baïnounk languages and completing the cycle from prefixed paired nouns to classless, plural-suffixed nouns.

\section{Conclusion}

This paper is a critical evaluation of theories advanced about nouns with plural suffixes and their agreement patterns in Baïnounk Guñaamolo and by extension in other Baïnounk languages with similar noun class systems by Sauvageot $(1967,1987)$. Sauvageot proposed to consider the nouns in question as prefixless and the agreement prefixes as copies of the CV onset of the noun stem. His claims have been reiterated by Dobrin (1995, 1998, 2012) who argues that phonological agreement-copying, or LAC (literal alliterative concord) in her terminology, is a rare phenomenon violating certain theoretical principles about the relationship between syntax and phonology. The data and analyses presented in this paper suggest that phonological agreement-copying of nounroot onsets onto agreement prefixes as first analysed by Sauvageot $(1967,1987)$ is not operational in any Baïnounk language. As a consequence, the claims made by Dobrin based on Sauvageot's data and analysis have to be revised as well. Taking into consideration recently published or collected data from various Nyun-Buy languages (Baïnounk Gubëeher, Baïnounk Guñaamolo, Baïnounk Gubelor, Kobiana) I show that the agreement behaviour of plural suffixed nouns can be less controversially explained by a unified hypothesis valid for all Baïnounk languages, including Guñaamolo. Table 18 summarises the arguments brought forth against the agreement-copying/LAC-hypothesis. Nouns with plural suffixes and alliterative agreement in Baïnounk languages are considered prefixed or in rare cases having fused prefixes. These nouns thus trigger ordinary alliterative agreement with a noun class prefix instead of phonological agreement-copying of the noun root onset.

As for the origin of the plural suffix, which is a feature typical of the Nyun languages, the following hypothesis is offered. A suffixed plural has developed at the stage of Proto Nyun-Buy, possibly from a nasal consonant marking plurality in TAM paradigms or from associative marking inherited from ProtoAtlantic and has spread to or across the nominal domain as a plural marker for animates. This has led to an erosion of prefixed plural marking for some noun 
Table 18: Summary of assessment of agreement-copying.

\begin{tabular}{|c|c|c|}
\hline & $\begin{array}{l}\text { Prediction, if LAC/purely } \\
\text { phonological copying applied }\end{array}$ & Observed facts \\
\hline Productivity & $\begin{array}{l}\text { LAC used to integrate loans from } \\
\text { classless languages }\end{array}$ & $\begin{array}{l}\text { No loans from prefixless languages are } \\
\text { attested in agreement type } 2 a \text {, on the } \\
\text { contrary many inherited items with cognates } \\
\text { in other Nyun. }\end{array}$ \\
\hline Semantic & $\begin{array}{l}\text { No sematic bias should be } \\
\text { detectable. }\end{array}$ & $\begin{array}{l}\text { Suffixed nouns include large amounts of } \\
\text { animate or certain subclasses of animates. }\end{array}$ \\
\hline Phonology & $\begin{array}{l}\text { All possible CV combinations } \\
\text { should occur as agreement } \\
\text { markers. }\end{array}$ & $\begin{array}{l}\text { A large proportion of possible } \mathrm{CV} \text { onsets are } \\
\text { not attested as agreement prefixes. }\end{array}$ \\
\hline Prefix status & $\begin{array}{l}\text { The initial CV sequence of the } \\
\text { noun is part of the stem. }\end{array}$ & $\begin{array}{l}\text { The initial CV sequence is a NC marker, at } \\
\text { least diachronically. }\end{array}$ \\
\hline Historical & $\begin{array}{l}\text { The plural suffixes borrowed } \\
\text { from Mandinka (Sauvageot } \\
\text { 1987: 20). }\end{array}$ & $\begin{array}{l}\text { The suffixes are well attested in all Nyun on } \\
\text { similar nouns and with similar function. The } \\
\text { split of Nyun must vastly predate the first } \\
\text { contact with Mandinka. }\end{array}$ \\
\hline
\end{tabular}

classes and left the nasal suffix as sole marker of plurality. With the massive influx of loanwords, the plural marking independent of noun classification has spread considerably, as it has offered a way to integrate loans from prefixless languages. The role of contact languages and speaker concentration on contact induced language change is considered as well, stipulating that the maintenance of a complex noun class system might be easier for a concentrated speaker community immersed into a cultural setting where languages with large, and similar, noun class systems are dominant.

Acknowledgments: I express my gratitude to the Volkswagen Stiftung for having funded research on the DoBeS project "Pots, plants and people" (2010-2013) led by Friederike Lüpke, within which I have conducted research on Baïnounk Gubëeher, pronounced, [gubə:her] as a PhD student and a postdoctoral researcher. I also thank the Leverhulme foundation for providing funding for the research project "Crossroads - investigating the unexplored side of multilingualism" hosted at SOAS and led by Friederike Lüpke. I was employed as postdoctoral researcher working on multilingualism involving Baïnounk Gubëeher and neighbouring Jóola languages in the Crossroads project from 2014 to 2016. 


\section{Abbreviations used}

$\begin{array}{ll}\text { 1/2/3 } & \text { First/ second/ third person } \\ \text { AGR } & \text { Agreement prefix } \\ \text { AUG } & \text { Augmentative } \\ \text { C } & \text { Consonant } \\ \text { CV } & \text { Consonant-Vowel onset } \\ \text { CL } & \text { (Noun) Class prefix } \\ \text { DEM } & \text { Demonstrative } \\ \text { DET } & \text { Determiner } \\ \text { DIM } & \text { Diminutive } \\ \text { DIST } & \text { Distal } \\ \text { eXcl. } & \text { Exclusive } \\ \text { INAC } & \text { Inactual } \\ \text { incl. } & \text { Inclusive } \\ \text { LAC } & \text { Literal alliterative concord } \\ \text { NC } & \text { Noun class } \\ \text { POSS } & \text { Possessive } \\ \text { PRO } & \text { Pronoun } \\ \text { PREP } & \text { Preposition } \\ \text { REL } & \text { Relative } \\ \text { SG } & \text { Singular } \\ \text { SUB } & \text { Subordinating } \\ \text { PL } & \text { Plural } \\ \text { V } & \text { Vowel }\end{array}$

\section{References}

Aikhenvald, Alexandra Y. 2003. Classifiers. A typology of noun categorization devices. Oxford/ New York: Oxford University Press.

Aronoff, Mark. 1997. Gender agreement as morphology. In Geert Booij (ed.), Proceedings of the first mediterranean conference of morphology, 7-18. Patras: University of Patras.

Bao Diop, Sokhna. 2015. Les classes nominales du nyun gunyamolo. In Denis Creissels \& Konstantin Pozdniakov (eds.), Les classes nominales dans les langues Atlantiques, 384-420. Köln: Rüdiger Köppe Verlag.

Bao-Diop, Sokhna. 2013. Description du baynunk guñaamolo, langue minoritaire du Sénégal. Analyse phonologique, morphologique et syntaxique. Paris: INALCO PhD thesis.

Basso Marques, João. 1947. Familiaridade idiomática entre Cobianas e Cassangas. Boletim Colonial Da Guine Portuguesa, 2(8). 875-913.

Bühnen, Stephan. 1988. Lexique comparatif des dialectes Bañun et de Kasanga et Cobiana (ms.). Childs, Tucker. 1983. Noun class affix renewal in South West Atlantic. In Jonathan D. Kaye, Hilda Koopman, Dominique Sportiche \& Andre Dugas (eds.), Current approaches to African linguistics II, 17-29. Dordrecht: Mouton de Gruyter; Foris Publications. 
Cobbinah, Alexander. 2010. The Casamance as an area of intense language contact. The case of Baïnouk Gubaher. Journal of Language Contact (THEMA 3). 175-201.

Cobbinah, Alexander. 2013. Nominal classification and verbal nouns in Baïnounk Gubëeher. London: University of London/ SOAS PhD Thesis.

Cobbinah, Alexander. to appear. Noun class semantics in Atlantic languages. In Friederike Lüpke (ed.), The Oxford guide to the Atlantic languages of West Africa. Oxford: Oxford University Press.

Cobbinah, Alexander \& Lüpke. Friederike 2014. When number meets classification. In Anne Storch \& Gerrit Dimmendaal (eds.), Number - Constructions and Semantics. Case studies from Africa, Amazonia, India and Oceania, 199-220. Amsterdam/Philadelphia: John Benjamins.

Creissels, Denis. to appear. 'Noun class systems in Atlantic languages'. In Friederike Lüpke (ed.), The Oxford guide to the Atlantic languages of West Africa. Oxford: Oxford University Press.

Dahl, Östen. 2000. Animacy and the notion of semantic gender. In Barbara Unterbeck, Matti Rissanen, Terttu Nevalainen \& Mirja Saari (eds.), Gender in grammar and cognition I. Approaches to gender, 99-115. Berlin: de Gruyter.

Demuth, Katherine. 2000. Bantu noun class systems. Loanwords and acquisition evidence of semantic productivity. In Gunter Senft (ed.), Systems of nominal classification, 270-202. Cambridge: Cambridge University Press.

Demuth, Katherine, Nicholas Faraclas \& Lynell Marchese. 1986. Niger-Congo noun class and agreement systems in language acquisition and historical change. In Colette Craig (ed.), Noun classes and Categorization, 453-472. Amsterdam/Philadelphia: John Benjamins.

Dimitriadis, Alexis. 1997. Alliterative Concord in Phonology-Free Syntax. Paper presented at the GLOW Workshop on the Morpho-Syntax and Phonology of African and Afro-Asiatic Languages. Rabat.

Dimmendaal, Gerrit J. 2001. Areal diffusion versus genetic inheritance: An African perspective. In Alexandra Y. Aikhenvald \& M. W. Dixon Robert (eds.), Areal diffusion and genetic inheritance, 358-392. Oxford/New York: Oxford University Press.

Dixon, Robert M. W. 1982. Where have all the adjectives gone? And other essays in semantics and syntax. Den Haag: Mouton.

Dobrin, Lise. 1995. Theoretical consequences of literal alliterative concord. Chicago Linguistic Society (regional Meeting) 31(1). 127-142.

Dobrin, Lise. 1998. The morphosyntactic reality of phonological form. In Geert Booij \& Jaap Van Marle (eds.), Yearbook of Morphology, 59-81. Dordrecht: Kluwer Academic Publisher.

Dobrin, Lise. 2012. Concreteness in Grammar: The Noun Class Systems of Papua New Guinea Arapeshan. Stanford Studies in Morphology and the Lexicon. Stanford: CSLI Publications.

Doneux, Jean Léonce. 1990. La place de la langue buy dans le groupe atlantique de la famille kongo-kordofan. Brussels: Université Libre de Bruxelles: PhD thesis.

Fudeman, Kirsten A. 1999. Topics in the morphology and syntax of Balanta, an Atlantic language of Senegal. Cornell University: PhD thesis.

Greenberg, Joseph. 1963. The languages of Africa. Bloomington: Indiana University Press.

Greenberg, Joseph. H. 1978. How does a language acquire gender markers? In Joseph H.

Greenberg (ed.), Universals of human language (vol. 3), 47-82. Stanford: Stanford

University Press.

Hetzron, Robert. 1972. Phonology in Syntax. Journal of Linguistics 8. 251-265.

Hopper, Paul J. \& Elizabeth C. Traugott 2003. Grammaticalization. Cambridge University Press: Cambridge. 
Lüpke, Friederike. to appear. Baïnounk Gujaher. In Friederike Lüpke (ed.), The Oxford guide to the Atlantic languages of West Africa. Oxford: Oxford University Press.

McLaughlin, Fiona. 2015. Inflection in Pulaar. In Matthew Baerman (ed.), The Oxford handbook of inflection, 419-445. Oxford: Oxford University Press.

Miller, Philip, Geoffrey K. Pullum \& Arnold M. Zwicky. 1997. The principle of phonology free syntax: Four apparent counterexamples in French. Linguistics 33. 67-90.

Mithun, Marianne. 1988. Lexical categories and the evolution of number marking. In Michael Hammond \& Michael Noonan (eds.), Theoretical morphology, 211-234. New York: Academic Press.

Quint, Nicolas. 2015. Le système des classes nominales en baïnouck (guñún) de Djifanghor (Basse-Casamance, Sénégal). In Denis Creissels \& Konstantin Pozdniakov (eds.), Les classes classes nominales dans les langues Atlantiques, 421-459. Köln: Rüdiger Köppe Verlag.

Sagna, Serge. 2008. Formal and semantic properties of the Gújjolaay Eegimaa. London: University of London/SOAS: PhD thesis.

Sapir, J. David. 1971. West Atlantic: An inventory. In Thomas Sebeok (ed.), Current Trends in Linguistics 7, 7:45-112. Den Haag/Paris: Mouton.

Sauvageot, Serge. 1967. Note sur la classification nominale en baïnouk. In Gabriel Manessy (ed.), La classification nominale dans les langues négro-africaines, 225-236. Aix-enProvence: Éditions du CNRS.

Sauvageot, Serge. 1987. La linguistique en tant que témoignage historique: Le cas du baynunk. In Jean Boulègue (ed.), Contributions à l'histoire du Sénégal, 17-22. Paris: Cahiers du C.R.A.

Seidel, Frank. to appear a. Baga Mandori. In Friederike Lüpke (ed.), The Oxford guide to the Atlantic languages of West Africa. Oxford: Oxford University Press.

Seidel, Frank. to appear b. Nalu. In Friederike Lüpke (ed.), The Oxford guide to the Atlantic languages of West Africa. Oxford: Oxford University Press.

Torrence, Harold. 2013. The clause structure of Wolof: insights into the left periphery. Amsterdam/Philadelphia: John Benjamins.

Voisin, Sylvie. 2015a. Les classes nominales en kobiana. In Denis Creissels \& Konstantin Pozdniakov (eds.), Les classes classes nominales dans les langues Atlantiques, 327-383. Köln: Rüdiger Köppe Verlag.

Voisin, Sylvie. 2015b. Sur l'origine du suffixe du pluriel dans le groupe ñuñ-buy. Linguistique et Langues Africaines 1(1). 13-42.

Wilson, William A. 2007. Guinea languages of the Atlantic group. Description and internal classification. Frankfurt am Main: Peter Lang.

Zwicky, Arnold M. \& Geoffrey K. Pullum. 1986. The Principle of Phonology-Free Syntax. Introductory remarks. Ohio State Working Papers in Linguistics 32. 63-91. 
Brought to you by | School of Oriental and African Studies (SOAS), University of London 